DOI https://doi.org/10.32841/2409-1154.2020.45-1.30 Romaniuk O.M.,
Lecturer at the Department of Foreign Languages and Culture of Professional Speech
Lviv State University of Internal Affairs

\author{
Zapotichna R.A., \\ Candidate of Economic Sciences, \\ Lecturer at the Department of Foreign Languages and Culture of Professional Speech \\ Lviv State University of Internal Affairs
}

\title{
THE NOTION OF TRANSLATION STRATEGY: THE MAIN PRINCIPLES
}

Summary. The article deals with the concept of "translation strategy". The notion "translation strategy" has not received an unambiguous definition in translation studies yet. In the present article the authors differentiate the terms translation strategy, translation tactics and method. The research of different scholars on the formulation of the term "translation strategy" is analyzed. The article focuses on the peculiarities of the use of the terms "global translation strategy" and "local translation strategy". The goal of global translation strategy is reproduction of the whole conceptual image of the source text. The local translation strategies are implemented through a set of approaches that determine the techniques, methods or procedures for translating specific linguistic units. The local strategy is aimed at reproduction of specific fragments of the text. The global translation strategies involve the local ones. There exist two main translation strategies: domestication and foreignization. Foreignization is focused more on the source culture and foreign nature of the text. Consequently, this method involves less interference with the original. The role of the translator in the translation process is considered. The problems which translator can face were singled out, among them: pragmatic translation problems, cultural, linguistic, and text specific translation problems. The translator must be familiar with the structure of the other language and their linguistic diversity. In the article the types of translation suggested by P. Newmark which differ in the focus - either on the source language or on the target language were defined. The principles and definitions of the main notions in translation studies are significant in the translation process. The very translation strategy presupposes the basis of the original text choice and the translation method or technique of its rendering that depends on the range of cultural, literal, linguistically and extralingual preconditions. In order to provide an adequate translation, the appropriate translation strategy should be chosen.

Key words: translation strategy, global translation strategies, local translation strategies, translation tactics, translation problems.

Introduction. The understanding of the translation process has changed qualitatively nowadays. Through the development of new technologies and the growing role of mass media, translation relations cover the present time practically in all areas of human life. Translation activity, in turn, determines the emergence of new translation challenges, requiring the search for appropriate translation strategies and solutions. The term "translation strategy" is very often used by translators-practitioners at the stage of pretranslation analysis of the text, and translators-theorists to describe the process translation. This concept is fundamental in translation studies, after all, almost no one can get along without it during the translation process.

Analysis of recent research and publications. The topic of the translation problems and the translator's strategies has been researched by different scholars throughout the world. Translation strategy is an object of translation studies of F. Schleiermacher, E. Nida, J. Levy, L. Venuti. There is no absolute agreement between them regarding the interpretation of this concept. Thus, it is of great importance to dwell upon this issue, since there are many distinctive factors to be taken into account when we analyze the translator's language, translation strategy or method. The topicality of the article lies in the necessity for investigating and analyzing the concept of "translation strategy" and make a thorough translation analysis. Lack of a single consistent system of translation principles, strategies, tactics, techniques and methods determines the relevance of the study.

The aim of the article is to define the main characteristics of the notion of translation strategy and the peculiarities of using the terms "global translation strategy" and "local translation strategy", "translation tactics" and other related concepts.

Presentation of the main research material. The term "strategy" is used in translation studies to denote a fairly wide range of translator's actions - from choosing a text for translation to determining how to reproduce specific linguistic units.

According to K. Chukovs'kyi, the translation is a great art. The translation should reproduce the spirit of source text by target language, but it should not be word-for-word translation. Translation should influence the reader in the same way as the original [2, p. 7-8].

The methodological and pedagogical direction of translation studies originates from the treatises on translation of the 17 th and 19th centuries, which prescriptively formulated the principles of translation, that is, they set themselves the goal of teaching the translator how to translate. It is from these positions that the development of a translation strategy is considered as part of the formation of the professional competence of a translator [2].

V. Sdobnikov proceeds from the understanding of strategy as planning the future activity, its preparation in relation to certain conditions and in accordance with a specific purpose. The researcher defines a strategy as an implementation program of translation activity, formed on the basis of the translator's general approach to performing a translation in a certain communicative 
situation of a bilingual communication, determined by the specific features of this situation, the purpose of translation and, in turn, determines the nature of professional behavior of translator within the framework of this communicative situation [5, p. 172]. We adhere to the definition of $\mathrm{V}$. Sdobnikov, since we consider it the most accurate, reflecting all aspects of this phenomenon.

Actually, when discussing the features of the translation process, researchers use not only the term "translation strategy", but also "strategy of the translator's behavior in the translation process", "translator's strategy" and even "translation tactics", considering these terms as synonyms. The problem of a distinct definition of the concept of "translation strategy" is also complicated because of the fact that different researchers put different content into this concept. Examination of different points of view about the content of the term "translation strategy" will help us to give a clear definition of this concept and thus identify the patterns of the translation process. It will serve as the basis for the development of a specific approach to the study of translation as a kind of human activity.

Translation strategies are the set of rules, aims and means used by the translator in the process of translation that outline his own specific style among other translators, and single out the translation product among other translations. The notion of translation strategies is considered to be very important in the process of translation. As the translator is the key figure in this process, the result of the translation directly depends on his ability to perceive the content of the original work, that should be rendered properly in the translation, and fulfil his task on the semantic, syntactic and pragmatic levels. It should be noted the practical importance of translation strategies. In the learning process, translators must master a wide spectrum of translation principles in order to develop translation competence and use them regularly. If this skill will work automatically, then such a skill will greatly simplify the work of the translator.

According to V. Komissarov, the translator's strategy covers three groups of general principles of the translation process: some initial principles, selection of a general course of action, which will guide the translator when making specific decisions; the choice of the nature and sequence of actions in the translation process. V. Komissarov in his book "Modern Translation Studies" defines strategy as "a kind of translation thinking, which underlies the actions of a translator". He emphasizes that the overall strategy of the translator is based on striving to understand the translated text as fully as possible and find the most accurate correspondence in the target language. The researcher notes that the most important strategic principles of the translator are a critical attitude to their actions and maximum efforts to find the best option of translation [3, p. 336-337].

The above-mentioned ideas give the translator the opportunity for further action to adequate translation, in addition, ensure the efficiency of the use of strategies in the translation process. Among the factors which determine the choice of a particular translation strategy are: the purpose of the translation, the type of text to be translated and the nature of the intended target reader [3, p. 337]. On the basis of the combination of these factors the required translation solutions are determined.

The notion of translation strategies has been also profoundly researched by the Western scholars. One of the theorists who have paid a great attention to this issue is L. Venuti. He states that translation strategies "involve the basic tasks of choosing the foreign text to be translated and developing the method to translate. Both of these tasks are determined by various factors: cultural, economic, and political" [6, p. 240]. It means that a translator should be aware of not only the language, or have his own approaches how to do it appropriately, but also be knowledgeable in the cultural, political and economic life of the source language. The last factor very often can play a significant role in the process of translation.

As the analysis of research on translation principles shows, even in early attempts to develop rules for a translator, the problem of choosing between the content and form of "thought" and "word", the need to preserve the spirit of the original, its style, to reproduce it by means characteristic of the target language, can be traced. Some discrepancies of the intentions of the translator and the author are possible.

While rendering from one language into another the translator may face a lot of problems and they are: pragmatic translation problems: (it arises from the particular transfer situation with its specific contrast of source text versus target text recipients); cultural translation problems : (these are a result of differences in culture-specific habits, expectations, norms and conventions concerning verbal and other behavior, general norms of style etc.); linguistic translation problems: (the structural differences between two language, particularly in lexical sentence structure, give rise to certain translation problems which occur in every translation); text specific translation problems : (any problems arising in particular text example which cannot be classified as pragmatic); cultural or linguistic, have to be classified as "text-specific" translation problems, which means that their occurance in a particular text is a special case). Thus, the translator must be familiar with the structure of the other language and their linguistic diversity. Indeed, to preserve the original in the reworded version, the process requires the translator's complete involvement in the life of source language. Translator's understanding of the original work should be clear, genuine and complete [1, p. 167-169].

Translation is the process of rendering of the source language (written or spoken) into the target language (written or spoken accordingly). It is a well-known fact that the aim of translation is to reproduce different types of text (religious, political, artistic, scientific, and many others) into another language. In such a way, one culture texts are closer to another culture-text readers and it helps the world to be united.

If language is a means of settings general and universal concepts, it must be very easy to render the information from one language into another. However, translation involves not only the word-forword translation but many other factors that include translation of form, style, meaning, proverbs, idioms, etc., since the concepts of the source language may be very different from those in the target language that leads to the gap between both languages. And the bigger this gap is, the more difficult the process of translation will be. The difference between cultures and languages can cause great challenges for the translators. Therefore, there exit several procedures and strategies for overcoming of these problems.

It should be mentioned that there are two main translation strategies: domestication and foreignization. L. Venuti was the first one who used these terms, indicating the two main strategies by which the translator is guided when solving linguistic and cultural issues. According to Venuti, domestication is an ethnocentric approach in which the original text is often shortened, the emphasis is on the cultural values of the target language, and "the author approaches the reader". Foreignization is an approach that 
emphasizes the preservation of foreign linguistic and cultural values, while "the reader approaches the author". The target culture dominance is impossible, because the method of foreignization is focused more on the source culture and foreign/source nature of the text. Consequently, this method involves the least interference with the original. Foreignization presupposes the choice of a foreign language text and the application of a translation method that emphasizes the distinctive features of the culture of the original text that are absent in the culture of the target language.

Generally, the translators distinguish between global translation strategies and local translation strategies. Global Translation Strategies (or translation methods) - are the strategies that the translator applies to a text as a whole. The global translation strategy is formed as a result of the translator's choice of the main principles, which in this situation seem to correspond to the communication goal, cognitive needs and interests of the target audience, and, according to the translator, take into account the main characteristics of the source text.

The aim of global translation strategy is reproduction of the whole conceptual image of the source text. The need to choose a local translation strategy arises when there is a problem, such as the "untranslatability" of a certain expression, the possibility of multiple solutions, the results of which are differently correlated with the chosen global strategy. The strategy is implemented through a set of approaches that determine the techniques, methods or procedures for translating specific linguistic units.

Knowledge of the principles of translation is a constant necessary component of the translator's competence and becomes the basis for the choice of techniques, methods, tactics, which, in turn, correlate with the global translation strategy. The formation of a global translation strategy is based on the translator's application of the basic principles of translation to specific text that correspond to the purpose of communication and the cognitive needs of the target audience.

According to P. Newmark, there are different types of translation. They differ in the focus - either on the source language or on the target language.

Thus, the source text/source language focus includes:

1) word-for-word translation. The aim of this type of translation is to preserve the word order and to provide literal translation of individual words, including cultural words. In most cases, this translation cannot be called appropriate as there may by some misunderstandings in the target text.

2) literal translation. It means to convert the individual words and grammatical structures of the original work into the nearest equivalents in the target work.

3) faithful translation. In the translation product the source language grammatical structures are also preserved (as in the previous type), but contextual factors are also taken into account.

4) semantic translation. Here the emphasis is laid more on naturalness and preserving the meaning of the original text than in faithful translation. The translation of certain cultural words is done by means of neutral equivalents in the target language. Therefore, it is important to admit that this type of translation is the most appropriate source language focus translation.

Target text/target language focus, in its turn, includes:

1) adaptation. It is the freest form of translation and more of a target language/culture based interpretation of the source text then a translation (it is sometimes called document design). In other words, the translator does the abridged translation aimed at specific audience: be it teenagers, children of preschool age or adults.

2) free translation. This type of translation is focused on the content of the target text rather than the form. It means that the same content is expressed in the target language but with very different grammatical structures that leads to some violation of the original work. Therefore, there are a lot of deviations on different levels but the thing is that the content is totally preserved.

3) idiomatic translation. In this translation the target text includes the idioms and colloquialisms while the original does not involve them. The translator renders the plain original text by means of colorful phraseological units of the target language. In this way, it is more interesting to read the translation than the original, since it is more appealing to the readers.

4) communicative translation. It is aimed at reproducing the exact message of the source text content into the target language, but the emphasis is laid more on naturalness and comprehensiveness of the target text readership [8].

Moreover, P. Newmark presupposes that the "culture specific items can be recognized quickly, since they have a long distance from target language culture, they are peculiar to source language and cannot be translated easily" [8, p. 32]. He asserts that cultural differences are more problematic than linguistic differences in the process of translation. It is possible to find equivalents for linguistic differences by means of clarification and explanation, but cultural differences are not easily translatable. The context and culture-bound element may pose potential problems to the translators.

Local Translation Strategies (translation procedure) - strategies that the translator applies in the translation of individual expressions in the source text, such as words, grammar constructions, idioms, etc. Local strategy is associated with the process of analyzing the original, selection of a certain fragment requiring application of translation solution, and the choice of direction for solving these translation problems in line with the overall translation strategy.

It is also important to distinguish between local strategies and tactics, since they are directed to different objects. Using the local strategies, the translator reproduces conceptual meaning or the function of a certain piece of text, and using tactics determines which semantic or formal the characteristics of the language units of the original text are subject to reproduction in translation to achieve the specified strategy. The application of translation strategies is based on logically interrelate translation tactics. Translation tactics is a specific speech action aimed at implementing a strategy and achieving the goal of translation at each stage.

We define the stages of translation as global translation strategies, and, therefore, each stage has its own global translation strategy. The global strategy of semantic processing corresponds to the stage of pre-translation text analysis. The global strategy for the selection of adequate equivalents is used at the stage of analytical variable search. At the stage of analysis of translation results, a global strategy of generalization of translation experience is implemented. At the stage of pre-translation analysis of the text, local strategies for overcoming linguistic difficulties are used.

Conclusions. In order to reproduce the original language by means of another language, the translator should choose the appropriate translation strategy. Thus, the method is a broader notion as it is viewed as a global translation strategy and the procedure is narrower which is included into the method. It is logical that 
the global translation strategies involve the local ones. But the very translation strategy presupposes the basis of the original text choice and the translation method/techniques of its rendering that depends on the range of cultural, literal, linguistically and extralingual preconditions. As a result, translation strategy is an even broader notion than method, since the reasons and the process of translation are overviewed within the translation strategy, and the method is a part of this strategy. Local strategies are based on translation tactics. In conclusion, it should be mentioned that in the translation process, translators are not able to adhere exclusively to one of the strategies discussed above. They need to define the type and genre of text in order to define a global strategy.

\section{References:}

1. Виноградов В.В. Стилистика. Теория поэтической речи. Поэтика. Москва : Изд-во АН СССР, 1963. 253 с.

2. Гайнічеру О. Поезія і мистецтво перекладу: Літ.-критич. нарис. Київ : Дніпро, 1990. 216 с.

3. Комиссаров В.Н. Общая теория перевода : учебное пособие. Москва : ЧеРо, Юрайт, 2000. 136 с.

4. Комиссаров. Современное переводоведение : учебное пособие. Москва : ЭТС. 2001. 424 с

5. Сдобников В.В. Стратегия перевода: общее определение. Вестник ИГЛУ. 2011. №1. С. 165-172.

6. Venuti L. Strategies of translation. Encyclopedia of translation studies. London, New York : Routledge. P. 240-244.

7. Venuti L. The Translator's Invisibility: A history of translation. London and New York : Routledge, 1995. 353 p.

8. Newmark P. A Textbook of Translation. New York and London : Prentice Hall, 1988. 292 p.

Романюк О. М., Запотічна Р. А. Поняття стратегії перекладу: основні принципи

Анотація. У статті досліджено поняття стратегії перекладу, яке ще не отримало однозначного визначення у перекладознавстві. Багато дослідників, науковців, студентів використовують терміни «стратегія перекладу», «метод перекладу», «тактика перекладу» та «стратегія поведінки перекладача в процесі перекладу» рівноцінно, а іноді з різними відтінками значення. У цій статті автори розрізняють вищезгадані терміни, зважаючи на те, що наукова термінологія повинна бути чіткою та однозначною. Проаналізовано дослідження різних учених щодо формулювання терміна «стратегія перекладу». Визначення В. Сдобнікова вважаємо найбільш точним, оскільки воно відображає всі аспекти цього явища. Визначено основні характеристики та підходи до поняття «стратегія перекладу». У статті зосереджено увагу на особливостях використання термінів «глобальна стратегія перекладу» та «локальна стратегія перекладу». Розглянуто роль перекладача у процесі перекладу. Перекладачі повинні оволодіти широким спектром принципів перекладу, щоб розвивати перекладацьку компетентність та регулярно ними користуватися. На думку В. Комісарова, стратегія перекладача охоплює три групи загальних принципів процесу перекладу: деякі початкові принципи, вибір загального курсу дій, яким керуватиметься перекладач у разі прийняття конкретних рішень; вибір характеру та послідовності дій у процесі перекладу. Дослідник зазначає, що найважливішими стратегічними принципами перекладача є критичне ставлення до своєї праці, щоб знайти найкращий варіант перекладу. Серед факторів, що визначають вибір конкретної стратегії перекладу, є: мета перекладу, тип тексту, який перекладається, та цільова аудиторія. На основі поєднання цих факторів визначаються необхідні перекладацькі рішення. Зазначено, що є дві основні стратегії перекладу: одомашнення та відчуження. Проаналізовано види глобальних стратегій перекладу та визначено випадки застосування локальних стратегій і тактик. Зроблено висновок, що в процесі перекладу тлумачі не можуть дотримуватися виключно однієї зі стратегій.

Ключові слова: стратегії перекладу, глобальні стратегії перекладу, локальні стратегії перекладу, тактика перекладу, проблеми перекладу. 